\title{
Biodiversity and Community Structure of Marine Benthic Organisms in the Rocky Shore of Dongbaekseom, Busan
}

\author{
Jong Su Yoo* \\ Research Institute of Marine Science and Technology, Korea Maritime University, Busan 606-791, Korea
}

\begin{abstract}
Species composition, community structure and biodiversity of marine benthic community were studied in the rocky shore of Dongbaekseom, Busan. A total of 82 species of marine algae including 4 Cyanophyta, 11 Chlorophyta, 20 Phaeophyta and 47 Rhodophyta are listed. The dominant algal species were Ulva pertusa, Chondria crassicaulis, Corallina spp. and Melobesioidean algae. Sargassum thunbergii, Chondracanthus intermedia, Gelidium divaricatum and Ralfsia verrucosa were subdominant in cases of different seasons and vertical layers. Chthamalus challengeri, Littorina brevicula and Mytilus edulis were dominant zoobenthic species upper-middle layer of the intertidal zone. The community structure of this area seemed to be controlled by spatial competition with benthic marine algae. The species diversity indices estimated from different sources were quite different. Indices from coverage were 1.87, 3.98 from frequency, 2.26 from the average of total frequency and coverage and 2.15 from importance value. The similarity indices on the present study showed decreasing trends comparing to the previous benthic algal composition researches.
\end{abstract}

Key Words: marine benthic community, rocky shore, community structure, biodiversity

\section{INTRODUCTION}

Records of coastal benthic marine algae in Korea were appeared in articles by foreigners (Okamura 1892; Cotton 1906; Grubb 1932). The first full scale floristic study was conducted by Kang (1960) and works by Kang (1966), Song et al. (1970), Lee (1972) and Lee and Boo (1981) were followed. The ecological study of marine algal community became popular science 1970s (Song 1971; Yoo and Lee 1980; Kim 1983; Lee et al. 1984; Sohn 1987; Yoo and Kim 1990). Recently studies on algal flora and community analysis have been decreased rapidly ever since the mid-1990s. After Kang's (1966) full-scale study on the coastal benthic marine algae of Busan, reports of Dongbaekseom, Gijang, Yonghodong and Busan coastal areas were followed (Lee and Kang 1971; Lee 1972, 1973; Lee et al. 1984, Kim 1991; Nam and Kim 1999).

Studies on the diversity, biomass, community structure and succession of benthic marine algae have provided the basic information of algal aquaculture and critical

*Corresponding author (jsyoo@hhu.ac.kr) background in studies of the distribution and growth of marine zoobenthos. In particular, marine algae plays an important role as a supplier of bioactive materials that are currently in the limelight, and they also enhances the coastal water quality by absorbing nutrients such as nitrogen and phosphorus. The quality of the coastal environment of Korea has been deteriorated due to the coastal development and population increase following the rapid economic growth since 1970s. Consequently, the biodiversity and community structure of marine benthic communities have been changed and the biological functions have been also seriously challenged.

This study was conducted to understand the effect coastal environment change caused by coastal urban development in Busan in terms of the species composition and community structure of marine benthic community, and to present the coherence of species diversity indices for geographical comparison.

\section{MATERIALS AND METHODS}

The sampling site was located at the southern extremity of Dongbaekseom, Busan, and samples were collected in each season - February, May, August and 
Table 1. Check list of benthic algal species observed at Dongbaekseom of Busan in 2002

\begin{tabular}{|c|c|c|c|c|}
\hline Species $\backslash$ Season & Spring & Summer & Autumn & Winter \\
\hline Entophysalis conferta & + & + & + & + \\
\hline Oscillatoria amphibia & + & + & + & + \\
\hline Sirocoeum kurzii & + & & & \\
\hline Enteromorpha compressa & + & + & + & + \\
\hline Enteromorpha linza & + & & & + \\
\hline Enteromorpha prolifera & & & & + \\
\hline Ulva conglobata & & + & & \\
\hline Ulva pertusa & + & + & + & + \\
\hline Codium fragile & + & & & \\
\hline Derbesia marina & + & & & \\
\hline \multicolumn{5}{|l|}{ Phaeophyta } \\
\hline Hincksia mitchellae & + & & & + \\
\hline Ralfsia verrucosa & + & + & + & + \\
\hline Sphacelaria sp. & + & & & \\
\hline Dictyopteris prolifera & + & + & + & + \\
\hline Dictyota dichotoma & & + & + & + \\
\hline Dilophus okamurae & + & & & \\
\hline Ecklonia stolonifera & + & + & + & + \\
\hline Undaria pinnatifida & + & & & + \\
\hline Hizikia fusiformis & + & & + & + \\
\hline Sargassum horneri & + & & + & + \\
\hline Sargasum siliquastrum & + & & & + \\
\hline Sargassum thunbergii & + & + & + & + \\
\hline Sargassum yezoense & & & + & + \\
\hline \multicolumn{5}{|l|}{ Rhodophyta } \\
\hline Stylonema alsidii & & & + & \\
\hline Porphyra suborbiculata & + & & & + \\
\hline Porphyra yezoensis & + & + & & + \\
\hline Amphiroa sp. & & & + & \\
\hline Corallina officinalis & + & + & + & + \\
\hline Corallina pilulifera & + & + & + & + \\
\hline Lithophyllum okamurae & + & + & + & + \\
\hline Marginisporum aberrans & & & & + \\
\hline Pneophyllum zostericolum & + & + & + & + \\
\hline Melobesioideaen algae & + & + & + & + \\
\hline Gelidium amansii & + & + & + & + \\
\hline
\end{tabular}


Table 1. (continued)

\begin{tabular}{|c|c|c|c|c|}
\hline Species $\backslash$ Season & Spring & Summer & Autumn & Winter \\
\hline Pteroclada capillacea & + & & & + \\
\hline Caulacanthus okamurae & + & + & + & + \\
\hline Dumontia simplex & + & & & + \\
\hline Gloiopeltis furcata & + & & & \\
\hline Chondracanthus intermedia & + & + & + & + \\
\hline Chondracanthus tenellus & + & + & + & \\
\hline Chondrus ocellatus & + & + & + & + \\
\hline Callophyllis sp. & + & & & + \\
\hline Ahnfeltiopsis flabelliformis & + & + & + & + \\
\hline Schizymenia dubyi & + & & & \\
\hline Carpopeltis affinis & & & & + \\
\hline Carpopeltis cornea & + & + & + & + \\
\hline Grateloupia elliptica & + & & + & + \\
\hline Grateloupia filicina & + & + & + & + \\
\hline Grateloupia lanceolata & + & + & + & + \\
\hline Grateloupia turuturu & + & + & + & + \\
\hline Plocamium telfairiae & + & & + & + \\
\hline Champia parvula & + & + & + & + \\
\hline Lomentaria catenata & + & & + & + \\
\hline Lomentaria hakodatensis & + & + & + & + \\
\hline Campylaephora crassa & + & + & + & \\
\hline Ceramium codii & + & + & + & \\
\hline Ceramium japonicum & & + & + & + \\
\hline Ceramium sp. & + & & & + \\
\hline Dasya sessilis & + & + & + & + \\
\hline Heterosiphonia japonica & & & & + \\
\hline Heterosiphonia pulchra & + & + & + & + \\
\hline Acrosorium polyneurum & + & + & + & + \\
\hline Chondria crassicaulis & + & + & + & + \\
\hline Laurencia intermedia & & & & + \\
\hline Laurencia okamurae & & & + & \\
\hline Laurencia undulata & + & & & \\
\hline Polysiphonia morrowii & + & + & + & + \\
\hline Symphyocladia latiuscula & + & + & + & + \\
\hline Symphyocladia marchantioides & + & & & \\
\hline
\end{tabular}

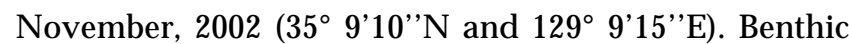
marine algae were collected for algal floral study in the intertidal zone. Samples were fixed in $10 \%$ formalin-seawater, then transported to the laboratory. The transported samples were washed with fresh water, then isolated with a stereomicroscope and light microscope. A $0.5 \mathrm{~m}$ $\times 0.5 \mathrm{~m}$ quadrat was set every 1 meter, along the line transect in the intertidal zone of the sampling site. The vertical zonation of marine benthic communities were studied by measuring the frequency and coverage of all species inside each quadrat. The frequency and coverage of dominant species in each quadrat were measured, and the average of total relative frequency and relative coverage calculated from the field survey was represent- ed as an importance value (IV). Species diversity index $\left(\mathrm{H}^{\prime}\right)$ used to show the stability of community which implies abundance and evenness (Peet 1974), and Shannon index $\left(\mathrm{H}^{\prime}=-\mathrm{Pi} \sum \log \mathrm{Pi}\right)$ was used in this study (Shannon and Weaver 1949). The difference of species diversity, according to coverage, frequency, average of total coverage and frequency, and importance value that can substitute Pi in benthic marine algae were compared. In addition, the previous floristic data in 1969-1970 and 1987-1990 were compared with the results of this study, to show the change in algal diversity before and after economic development (Lee and Kang 1971; Kim 1991). Sørensen's index was used as similarity index (Sørensen 1948). 
Table 2. The number of benthic algal species observed at Dongbaekseom of Busan in 2002

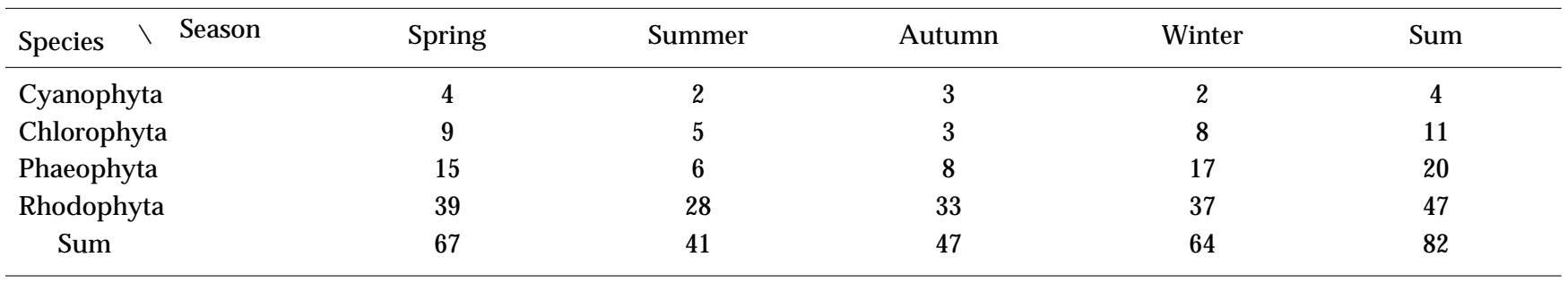

Table 3. The importance value (IV) of benthic marine algae by each season based on relative frequency and relative coverage at Dongbaekseom of Busan in 2002

\begin{tabular}{|c|c|c|c|c|c|}
\hline Species \Season & Spring & Summer & Autumn & Winter & Sum \\
\hline Ulva pertusa & 25.30 & 26.08 & 13.33 & 15.83 & 80.53 \\
\hline Chondria crassicaulis & 1.24 & 17.56 & 29.57 & 23.90 & 72.27 \\
\hline Corallina spp. & 16.66 & 27.08 & 6.26 & 1.53 & 51.54 \\
\hline Melobesioidean algae & 10.21 & 10.35 & 12.26 & 12.06 & 44.87 \\
\hline Gelidium divaricatum & 6.22 & 11.15 & 6.03 & 6.28 & 29.68 \\
\hline Ralfsia verrucosa & 4.64 & 0.00 & 15.64 & 8.38 & 28.65 \\
\hline Sargassum thunbergii & 8.16 & 5.76 & 1.92 & 6.85 & 22.68 \\
\hline Chondracanthus intermedia & 10.70 & 0.21 & 2.38 & 2.77 & 16.05 \\
\hline Sargassum horneri & 4.65 & 0.00 & 0.61 & 2.09 & 7.35 \\
\hline Lomentaria hakodatensis & 2.06 & 0.07 & 2.56 & 2.50 & 7.20 \\
\hline Acrosorium polyneurum & 0.54 & 0.34 & 3.96 & 2.20 & 7.05 \\
\hline Pophyra spp. & 1.55 & - & 0.37 & 3.94 & 5.86 \\
\hline Enteromorpha compressa & 0.11 & - & - & 4.80 & 4.91 \\
\hline Colpomenia sinuosa & 3.55 & - & - & 0.87 & 4.43 \\
\hline Symphycladia latiuscula & 0.32 & 0.21 & 2.08 & 1.34 & 3.94 \\
\hline Lithophyllum okamurae & 1.50 & 0.07 & - & 0.05 & 1.63 \\
\hline Dilopus okamurae & - & - & - & 1.33 & 1.33 \\
\hline Hizikia fusiformis & 0.54 & - & 0.11 & 0.67 & 1.31 \\
\hline Champia sp. & - & - & 1.24 & - & 1.24 \\
\hline Ahnfeltiopsis okamurae & 0.28 & 0.07 & 0.37 & 0.51 & 1.23 \\
\hline Polysiphonia morrowii & 0.33 & - & 0.79 & 0.07 & 1.19 \\
\hline Colpomenia bullosa & 0.75 & - & - & 0.26 & 1.01 \\
\hline
\end{tabular}

\section{RESULTS AND DISCUSSION}

There was a total of 82 species with 4 Cyanophyta, 11 Chlorophyta, 20 Phaeophyta and 47 Rhodophyta (Table 1). There was a total of 67 algal species in spring, 64 in winter, 42 in summer and 47 in autumn, which showed that there were more species in spring and winter season (Table 2). The percentage of the divisional algal composition were $4.9 \%$ of Cyanophyta, $13.4 \%$ of Chlorophyta, $24.4 \%$ of Phaeophyta, and $57.4 \%$ of Rhodophyta. There was little seasonal change in the number of Cyanophya; there were more Chlorophyta in spring and winter than in autumn; the number of Phaeophyta was highest in winter and reduced in the order of spring, autumn and summer; and the number of Rhodophyta was high in

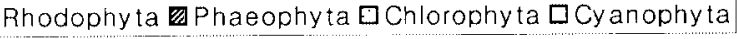

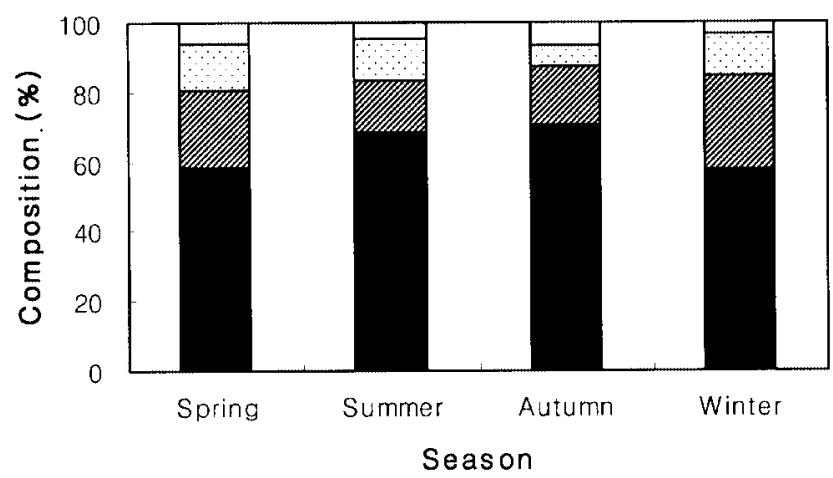

Fig. 1. Seasonal variation in the composition of marine benthic algal community at Dongbaekseom of Busan. 
Rhodophyta $\otimes$ Phaeophyta $⿴$ Chlorophyta
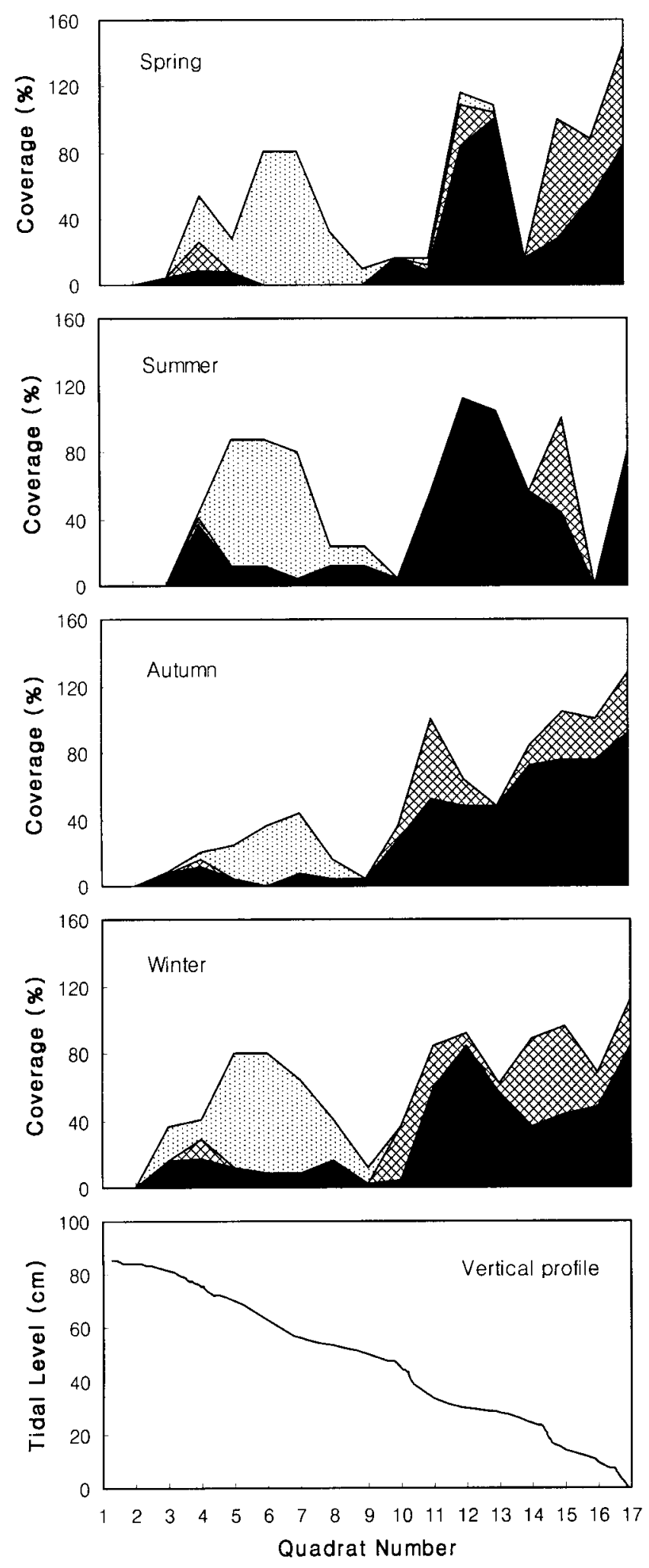

Fig. 2. Seasonal coverage variation of vertical algal distribution patterns along the line transect at Dongbaekseom of Busan.

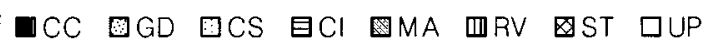
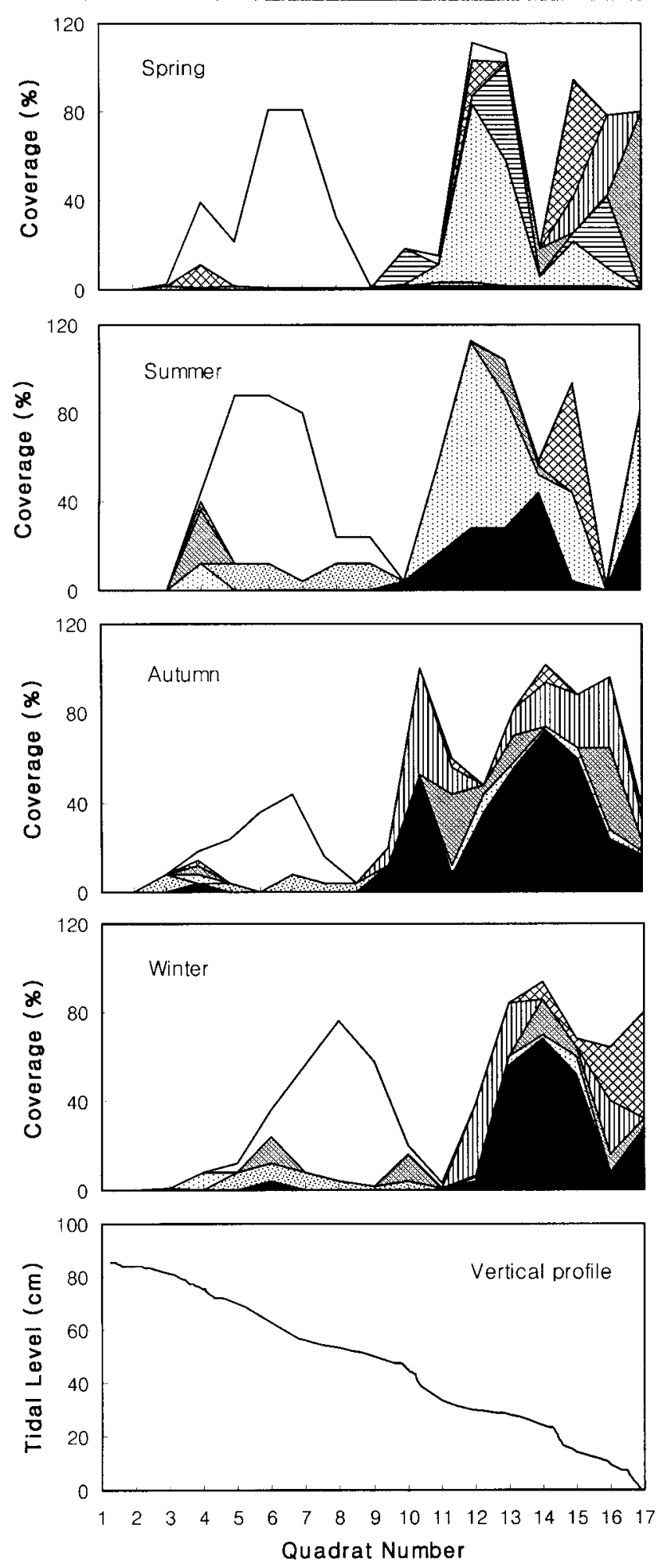

Fig. 3. Seasonal variation of vertical algal distribution patterns by each division on the coverage of main benthic marine algae studied in each quadrat along the line transect at Dongbaekseom of Busan. (CC: Chondria crassicaulis, CS: Corallina spp., CI: Chondracanthus intermedia, GD: Gelidium divaricathum, MA: Melobesioidean algae, RV: Ralfsia verrucosa, ST: Sargassum thubergii, UP: Ulva pertusa). 
spring and reduced in the order of winter, autumn and summer (Fig. 2). There was higher number of Rhodophyta in summer and autumn and there was lower number of Phaeophyta compared to other seasons. It is speculated that the life history of Phaeophyta is closely related to summer and autumn when the water temperature is relatively high. Meanwhile, the species observed in all four seasons were a total of 35 species 2 Cyanophyta, 3 Chlorophyta, 7 Phaeophyta and 23 Rhodophyta - which was $43 \%$ of the total number of species.

The marine benthic algal species with importance value is as shown in Table 3. Considering marine benthic algal species with importance value of above 10 as dominant species; Ulva pertusa, Corrallina spp. Chondracanthus intermedia and Melobesioidean algae (4 species) were dominant in spring; Corallina spp., Ulva pertusa, Chondria crassicaulis, Gelidium divaricatum and Melobesioidean algae (5 species) in summer; Chondria crassicaulis, Ralfsia verrucosa, Ulva pertusa and Melobesioidean algae (4 types) in autumn; and Chondria crassicaulis, Ulva pertusa and Melobesioidean algae (3 species) in winter. Meanwhile, considering benthic marine algal species with importance value of above 40 as dominant species in all seasons, Ulva pertusa was dominant in the upper and middle layer of the intertidal zone; Chondria crassicaulis, Corallina spp. and Melobesioidean algae in the middle and lower layer; and Sargassum thunbergii was subdominant in the lower layer. In addition, there was an addition of Chondracanthus intermedia in the lower layer in spring; Gelidium divaricatum in the upper and middle layer in summer; and Ralfsia verrucosa in the lower layer in autumn.

The vertical distribution pattern of coverage of marine benthic algae is shown in Fig. 2. There was high coverage of Chlorophyta in the upper layer and middle layer of the intertidal zone. This tends tended to be high in spring and summer, and lower in autumn. Generally, there was high coverage of Phaeophyta in the lower layer, and it was high in winter and low in summer. Rhodophyta was distributed throughout the intertidal zone, but there was higher coverage below the middle layer. The coverage of Rhodophyta was highest in the intertidal zone except the upper layer. The pattern of the vertical distribution pattern of major benthic algal species are shown in Fig. 3. Ulva pertusa was dominant in the upper and middle layer of the intertidal zone, and showed high coverage in spring and summer, and low in autumn. Ralfsia verrucosa and Sargasumm thunbergii
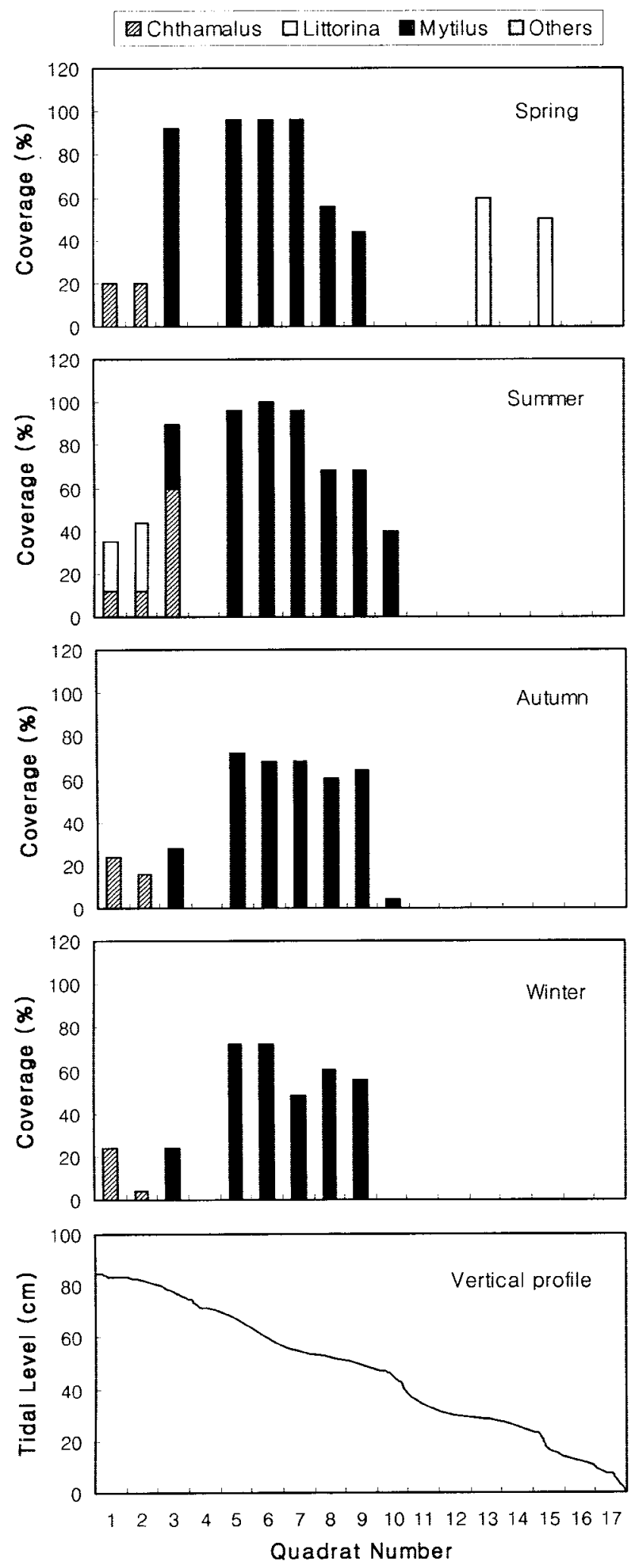

Fig. 4. Seasonal variation of vertical faunal distribution patterns by each division on the coverage of main zoobenthos studied in each quadrat along the line transect at Dongbaekseom of Busan. (Chthamalus: Chthamalus challegeri, Littorina: Litohrina brevicula, Mytilus: Mytilus edulis, Others: Cellana toreuma, Granulilittorina exigua, Liolophura japonica, and Reishia clavigera). 


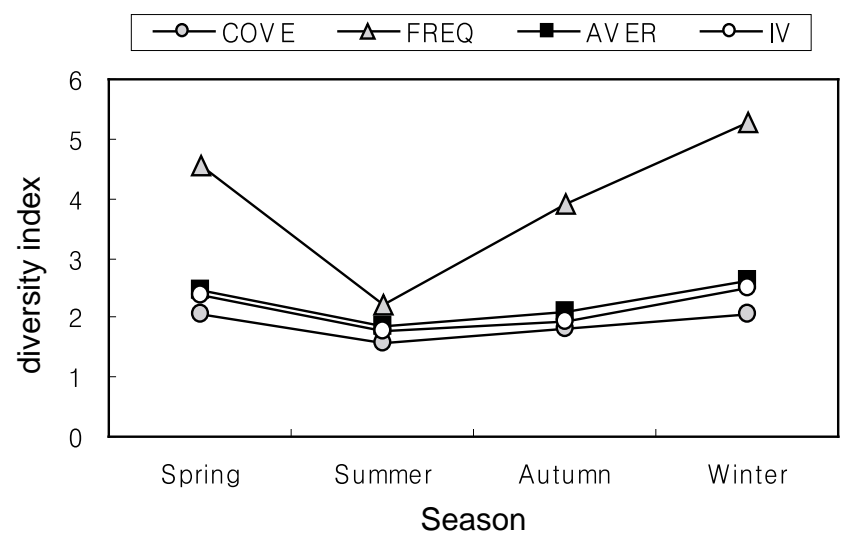

Fig. 5. Comparison of species diversity index $\left(\mathrm{H}^{\prime}\right)$ of marine benthic algal community from difference source data at Dongbaekseom of Busan. (COVE: coverage, FREQ: frequence, AVER: average of frequence and coverage, IV: importance value).

were dominant in the lower layer in autumn and winter. Corallina spp. was dominant in the mid-lower layer with especially high coverage in spring and summer. There was the highest coverage of Melobesioidean algae in autumn, due to relatively light condition when the abundance of other benthic algal communities were low. Chondria crassicaulis was dominant from the middle to lower layer, and the coverage decreased in the order of autumn $>$ winter $>$ summer $>$ spring. The coverage was low in spring caused by human disturbance (seaweed collector as Undaria pinnatifida, Hizikia fusiformis).

The vertical distribution pattern of zoobenthos is as shown in Fig. 4. Chthamalus challengeri was dominant in the uppermost layer and Littorina brevicula was dominant in the lower layer. Mytilus edulis showed a distribution pattern that was dominant with high coverage from the lower limiting layer where its species were distributed to the middle layer of the intertidal zone. It could be observed that Mytilus edulis was dominant with high coverage from quadrats 3 to 10 (Figs. 3 and 4). In addition, Ulva pertusa on the nussel shell was also dominant with high coverage in the same location.

The species diversity indices of each season in Dongbaekseom were estimated from coverage, frequency, average of total coverage and frequency, and importance value (Fig. 5). The species diversity index based on coverage was $1.87 ; 3.98$ from frequency; 2.26 the from average of total coverage and frequency; and 2.15 from importance value. The value were different according the source data for estimating the species diversity index. The species diversity index tends to be low from coverage data source, high from frequency. All species diversity indices from any source were high in winter and decreased in the order of spring, autumn and summer. Value of 1.5-2.6 was reported by Nam and Kim (1999) in Yongho-dong, Busan, and the results are similar to this study, except the results based on coverage. Kim (1991) reported the algal diversity indices to be 1.73.3 in Gori, $50 \mathrm{~km}$ north of Busan, it was higher than the results of this study, except results based on frequence. In the previous study on benthic algal community of Dongbaekseom by Lee (1973), seven typical patterns were reported - 1) Capsosiphon fulvescens - Gloiopeltis furcata association, 2) Ulva pertusa - Myelophycus simplex association, 3) Enteromorpha liza - Colinsiella cava association, 4) Monostroma grevillei - Scytosiphon lomentaria association, 5) Hizikia fusiformis association, 6) Chondrus ocellatus association, and 7) Eckonia cava - Undaria pinnatifida association. The algal community structure has completely changed since that report. Population of Ulva pertusa, Hizikia fusiformis, Chodrus ocellatus, and Undaria pinnatifida have been persisted. However, Kim (1991) reported the dominance of Ulva pertusa and Gloiopeltis furcata in the upper layer of intertidal zone, and the algal composition of Sargassum thunbergii, Ahnfeltiopsis flabelliformis, Carpopeltis cornea and Chondracanthus intermedia in the middle and lower layer, in the same research site. The distribution pattern was more similar to this result than that of Lee (1973). The similarity indices reported in the studies of Lee and Kang (1971) and Kim (1991) were 0.45 and 0.61 the similarity index between those of Lee and Kang (1971) and Kim (1991) was 0.64. It clearly shows that the community structure changed greatly for 30 years.

The recent rapid change in the quality and quantity if coastal environment caused by human activities resulted in the serious threat to biodiversity conservation. In order to understand such change in biodiversity, continuous monitoring should be conducted under the standard protocol with multidisciplinary cooperation of related fields.

\section{ACKNOWLEDGEMENT}

This work was supported by the Korea Research Foundation Grant (KRF-2002-005-F00004).

\section{REFERENCES}

Cotton A.D. 1906. Marine algae from Corea. Bull. Misc. Inform., 
Royal Bot. Gard., Kew 1906: 366-373.

Grubb V.M. 1932. Marine algae of Korea and China with notes on the distribution of Chinese marine algae. J. Bot. 70: 213251, 245-251.

Kang J.W. 1960. The summer algal flora of Cheju Island (Quelpart Island). Bull. Pusan Fish. Coll. 3: 17-23.

Kang J.W. 1966. On the geographical distribution of marine algae in Korea. Bull. Pusan Fish. Coll. 7: 1-125.

Kim H.G. 1991. The characteristics of algal vegetation in relation to environmental factors around Pusan and its vicinity. NFUP, Busan. 144 pp.

Kim Y.H. 1983. An ecological study of algal communities in intertidal zone of Korea. Ph. D. thesis. SNU, Seoul. 175 pp.

Lee I.K. 1972. Notes on marine algae from Korea (I). Korean J. Bot. 15: 13-22.

Lee I.K., Kim H.S., Koh D.J., Kang J.W., Hong S.Y., Boo S.M., Kim I.H. and Kang Y.C. 1984. Studies on the marine benthic communities in inter- and subtidal zone. 2. Qualitative and quantitative analysis of the community structure in south-eastern coast of Korea. Proc. Coll. Nature. Sci. SNU 9: 71-126.

Lee I.K. and Boo S.M. 1981. Marine algal flora of Ulreung and Dogdo Islands. Rep. KACN 19: 201-214.

Lee K.W. 1972. Annual variation of marine algal flora at Dongbaeksum. Bull. Fish. Jeju Univ. 1: 8-16.

Lee K.W. 1973. Observation of algal community near Dongbaeksum, Haeundae. Cheju Univ. Jour. 5: 319-331.

Lee K.W. and Kang J.W. 1971. A preliminary survey of the algal flora and communities of Dongbaeksum, Pusan. Publ. Mar. Lab. Pusan Fish. Coll. 4: 29-37.
Nam K.W. and Kim Y.S. 1999. Benthic marine algal flora and community structure of Yongho-dong area in Pusan, Korea. J. Korean Fish. Soc. 32: 374-384.

Okamura K. 1892. On the marine algae of Fusanpo. Bot. Mag. Tokyo 6: 117-119.

Peet R.K. 1974. The measurement of species diversity. Ann. Rev. Ecol. Syst. 5: 285-307.

Shannon C.E. and Weaver W. 1949. The Mathematical Theory of Communication. Board of Trustees of Univ. III. Urbana. 117 pp.

Sohn C.H. 1987. Phytogeographical characterization and quantitative analysis of algal communities in Korea. Ph.D. thesis. CNU, Gwangju 111pp.

Song S.H. 1971. Phytosociological study of marine algae at Odong-do. Bull. Korean Fish. Soc. 4: 105-112.

Song S.H., Choe J.S. and Son C.H. 1970. Summer algal flora at Odongdo, Yeosu. Thesis Collect. Yeosu Fish. tech. Coll. 4: 1828.

Sørensen T. 1948. A method of establishing groups of equal amplitude in plant sociology based on similarity of species content. Biol. Skr., K. danske Vidensk Selsk. 5: 1-34.

Yoo J.S. and Kim Y.H. 1990. Structure analysis of intertidal algal communities in Muchangpo and Maryangri, western coast of Korea. Korean J. Bot. 33: 225-236.

Yoo S.A. and Lee I.K. 1980. A study on the algal communities in the south coast of Korea. Pro. Coll. Natur. Sci., SNU. 5: 109138.

Received 6 September 2003

Accepted 25 September 2003 